\title{
Overexpression of Proenkephalin in the Amygdala Potentiates the Anxiolytic Effects of Benzodiazepines
}

\author{
Wen Kang, Ph.D., Steven P. Wilson, Ph.D., and Marlene A. Wilson, Ph.D.
}

To elucidate the role of opioid peptides in control of the anxiety-like behavior and anxiety-reducing actions of benzodiazepines, a recombinant, replication-defective herpes virus (SHPE) carrying human preproenkephalin $c D N A$ was delivered to rat amygdala. Viral infection resulted in a strong, localized transgene expression after 2-4 days which diminished after one week. Anxiety-like behavior and the anxiolytic effect of diazepam were assessed three days after gene delivery using the elevated plus maze test. While SHPE infection alone did not reduce anxiety-like behavior, rats infected with SHPE exhibited a greater response to the anxiolytic effect of diazepam when compared to rats infected with a control virus (SHZ.1) containing the lacZ gene. The enhancement of diazepam action by SHPE was naloxone reversible, region-specific, and correlated with the time course of preproenkephalin expression. The findings implicate amygdalar opioid peptides in regulating the anxiolytic effects of benzodiazepines. This study also demonstrates the usefulness of recombinant herpes virus in evaluating the role of single gene products within specific brain sites in pharmacological responses and complex behaviors. [Neuropsychopharmacology 22:77-88, 2000] (C) 1999 American College of Neuropsychopharmacology. Published by Elsevier Science Inc.
KEY WORDS: Amygdala; Anxiety; Benzodiazepines; Opioid peptides; Gene transfer; Herpes virus vectors

In addition to its well known role in mediating fear and anxiety responses (Davis et al. 1994), the amygdala may also be a key neural substrate for the anxiolytic actions of benzodiazepines. Benzodiazepines (BZs) are believed to induce their anxiolytic properties by binding to GABA/benzodiazepine receptors in the brain (Haefely 1990). In addition, the amygdala has a high density of GABA/benzodiazepine receptors (Young and Kuhar 1980; Richards and Mohler 1984). Local infu-

From the Department of Pharmacology and Physiology, University of South Carolina School of Medicine, Columbia, SC. Dr. W. Kang current address: Department of Microbiology, University of Pennsylvania Medical School, Philadelphia, PA.

Address correspondence to: Dr. Marlene A. Wilson, Department of Pharmacology and Physiology, University of South Carolina School of Medicine, Columbia, SC 29208.

Received April 29, 1999; revised July 21, 1999; accepted July 22, 1999. sion of benzodiazepine agonists into the amygdala produces anxiolytic effects which can be blocked by co-administration of $\mathrm{GABA}_{\mathrm{A}}$ or benzodiazepine antagonists (Scheel-Kruger and Petersen 1982; Petersen et al. 1985; Pesold and Treit 1994, 1995). Furthermore, the anxietyreducing actions of systemic benzodiazepines can be blocked by intra-amygdala injection of GABA/benzodiazepine antagonists (Sanders and Shekhar 1995).

The amygdala also has high levels of endogenous opioid peptides and opioid receptors (Loughlin et al. 1995), and opioid mechanisms have been implicated in many biological functions, including nociception, memory, and fear conditioning (Good and Westbrook 1995; McGaugh et al. 1996; Valverde et al. 1996). A partial anxiolytic action has been reported following microinjection of morphine into amygdala (File and Rodgers 1979).

Although opioid agonists are not used as anxiolytics in general, recent evidence strongly indicates a role for endogenous opioid peptides in the control of stress and anxiety (Olson et al. 1996). Preproenkephalin knockout 
mice have elevated level of anxiety-like behavior and aggression (Konig et al. 1996), and some novel к-opioid agonists show anxiolytic properties (Privette and Terrian 1995). Several lines of evidence also indicate the involvement of endogenous opioid peptides in various aspects of benzodiazepine action, including their influences on food intake, locomotor activity, conflict, and anxiety-like behaviors (Millan and Duka 1981; Cooper 1983; Nowakowska and Chodera 1990). Interestingly, clinical studies suggest interactions between responses to benzodiazepines and opioids in humans (Darke et al. 1993). The anxiolytic effects of benzodiazepines can be blocked by opioid antagonists in both humans and laboratory animals (Billingsley and Kubena 1978; Koob et al. 1980; Duka et al. 1981, 1982; Agmo et al 1995; Tsuda et al. 1996).

Prior studies using herpes virus-mediated gene transfer demonstrated that overexpression of proenkephalin in amygdala produced antinociceptive effects, and illustrated the usefulness of this methodology for examining the role of neuropeptides in behavioral responses (Kang et al. 1998). To investigate if modifying opioid peptides in the amygdala altered anxiety-like behavior or the anxiolytic effects of benzodiazepines, a herpes virus vector (SHPE) expressing human preproenkephalin was delivered to the rat amygdala. Effects on anxiety-like behavior as well as the anxiolytic effect of diazepam were examined using the elevated plus maze test after the gene delivery.

\section{MATERIALS AND METHODS}

\section{Recombinant Viruses}

Initial stocks of replication-defective, ICP4-herpes viruses encoding either lacZ (SHZ.1; formerly named DZ) (Mester et al. 1995) or human preproenkephalin (SHPE) (Kang et al. 1998) under control of human cytomegalovirus immediate-early promoter/enhancer and the complementing $7 \mathrm{~B}$ cell line were generously provided by J. C. Glorioso and M. A. Bender at the University of Pittsburgh.

\section{Subjects, Surgery, and Infection}

This study was approved by the Institutional Animal Care and Use Committee of the University of South Carolina; the Principles for Care and Use of Laboratory Animals of NIH were followed in all experimental procedures. Adult male Long-Evans rats (Harlan) weighing 225-280 g were individually housed and maintained on a 12:12 h light/dark cycle with food and water available ad libitum.

Animals were handled daily and surgery was performed under phenobarbital anesthesia $(65 \mathrm{mg} / \mathrm{kg}$
Nembutal, i.p.). Rats were placed on the stereotaxic apparatus (David Kopf, Tajunga, CA) , and the virus suspension was injected bilaterally into amygdala using a $10 \mu \mathrm{l}$ Hamilton syringe with a 26-gauge needle (Hamilton \# 80427) using the coordinates of AP $-2.4, \mathrm{LM} \pm 4.6$, DV -8.5 from bregma (Paxinos and Watson 1997). Viruses were suspended in cell culture medium with $10 \%$ glycerol. One microliter viral stock of SHPE or SHZ, containing about $2 \times 10^{6}$ plaque forming units (pfu), was injected by hand at a speed of $0.2 \mu \mathrm{l} / \mathrm{min}$ followed by $10 \mathrm{~min}$ diffusion period before needle withdrawal. Additional control groups received either bilateral virus injection in the caudate (coordinates: $\mathrm{AP}+0.5$, LM 土3.5, DV-6.0 from Bregma) (Paxinos and Watson 1997) or vehicle-injection (10\% glycerol in cell culture medium) in the amygdala. Animals were allowed to recover after the surgery and monitored daily for general health (body weight, food and water intake, grooming behaviors).

For microinjection studies, bilateral 26-gauge guide cannulae precut to $9 \mathrm{~mm}$ below the pedestal (C315G; Plastics One, Roanoke VA) were aimed at the central amygdala using the same AP and LM coordinates as above, but lowered $-7.7 \mathrm{~mm}$ from the top of skull (Paxinos and Watson 1997). Guide cannulae were attached to the skull using skull screws and cranioplastic cement (Plastics One, Roanoke, VA), and guides were protected using dummy cannulae (C315DC; Plastics One, Roanoke, VA). Animals were habituated to removal of the dummy cannulae after surgery.

\section{Elevated Plus Maze Test}

The elevated plus maze apparatus consisted of two opposing open arms $(50 \times 10 \mathrm{~cm})$ and two closed arms $(50 \times$ $10 \times 40 \mathrm{~cm}$ high walls) connected with a center platform $(10 \times 10 \mathrm{~cm})$ and elevated $50 \mathrm{~cm}$ above the floor (Pellow et al. 1985). Each arm was marked into three equal divisions for better analysis of activity (entries into each of the three divisions). Tests were conducted either three or nine days after surgery. Thirty minutes before testing rats received an intraperitoneal injection of either vehicle (10\% ethanol, $40 \%$ propylene glycol, i.p.) or diazepam $(1 \mathrm{mg} / \mathrm{kg}$; a generous gift of F. Hoffmann-LaRoche LTD, Basel Switzerland). This dose of diazepam produces sub-maximum increases in open arm measures in the plus maze (in our laboratory), thus allowing the observation of potentiation in these measures.

In some rats naloxone hydrochloride $(5 \mathrm{mg} / \mathrm{kg}$, i.p.; Sigma Chemical Co., St. Louis, MO) was given simultaneously with diazepam. The elevated plus maze tests were conducted between 10:00 to 12:00 am during the early light part of the 12:12 light: dark cycle. At the beginning of each test session rats were placed in the center 
platform with the head facing a closed arm, and allowed to freely explore for $10 \mathrm{~min}$. The behavior was recorded by a videocamera mounted above the field, to allow the number of arm entries and time spent in each arm to be scored at a later time by an observer blind to the treatment condition. A reduced anxiety state was indicated by increased open arm activities, which were quantified as the amount of time that rat spent in the open arm relative to the total amount of time spent in any arm, as well as the number of entries into open arms relative to the total number of entries into any arm. The number of closed arm entries (all three divisions on both arms) was used a measure of locomotor activity. Each animal was tested only once and those that showed less than 12 total entries (12 divisions on four arms) were excluded from data analysis. Rats were tested in several groups of eight to insure the reproducibility of the results.

To examine opioid-benzodiazepine interactions using alternate techniques, an additional study examined if local administration of the opioid antagonist naltrexone into the amygdala could attenuate the anxiolytic actions of diazepam. A higher, more effective dose $(2 \mathrm{mg} / \mathrm{kg})$ of diazepam was used in these experiments to allow assessment of naltrexone-induced attenuation in benzodiazepine effects. For microinjection studies, bilateral indwelling cannulae were positioned stereotaxically (see above) 5-10 days before testing. Rats received bilateral injections of sterile saline $(1 \mu \mathrm{l})$ the day before testing to habituate them to the injection procedure. The day of testing, rats received bilateral injection of either sterile saline $(1 \mu \mathrm{l})$ or naltrexone ( $20 \mu \mathrm{g}$ in $1 \mu \mathrm{l}$ of sterile saline) using a 33gauge internal cannula extending $1 \mathrm{~mm}$ beyond the guide cannula (C215I; Plastics One, Roanoke, VA). Injections were done over $1.5 \mathrm{~min}$, and the internal cannula was left in place an additional $1.5 \mathrm{~min}$ while the animal was gently restrained. Immediately after microinjection, animals received $2.0 \mathrm{mg} / \mathrm{kg}$ diazepam (i.p.) and were tested for anxiolytic actions of diazepam on the elevated plus maze 30 min later as described above. Animals were perfused, and cannula placement was verified histologically. Only animals with both cannulae placed for injection into the central area of the amygdala were included in analysis.

\section{Data Analysis}

The behavioral measures were compared using analysis of variance (ANOVA) or $t$-test (experiments with only two groups). When overall ANOVAs reached statistical significance $(\alpha=0.05)$, Bonferroni's multiple comparison tests were performed to assess specific group differences.

\section{Histochemical Procedures}

Immediately after testing, rats were sacrificed with an overdose of chloral hydrate and transcardially perfused with phosphate-buffered saline followed by $4 \%$ paraformaldehyde in $0.1 \mathrm{M}$ sodium phosphate ( $\mathrm{pH} 7.6$ ). Brains were rapidly removed, post-fixed in the same solution overnight, and soaked in $15 \%$ sucrose in $0.1 \mathrm{M}$ sodium phosphate ( $\mathrm{pH} 7.6)$ for $24 \mathrm{hrs}$. Tissue sections were cut on a freezing microtome and processed for histological analysis. Brains infected with SHZ.1 virus (50 $\mu \mathrm{m}$ sections) were reacted for $\beta$-galactosidase (Dobson et al. 1990) and counterstained with neutral red. Brains infected with SHPE virus ( $25 \mu \mathrm{m}$ sections) were mounted on silane-coated slides and processed for expression of human preproenkephalin mRNA by nonradioactive in situ hybridization using a modification of the procedure described in Paradies and Steward (1997). Only animals with confirmed needle placements were included in the data collection.

Synthesis of Digoxigenin-labeled hPPE mRNA probes. A plasmid designated pGEMhPPE was constructed by inserting human preproenkephalin cDNA obtained from plasmid pUR292- $\beta$ Gal-hPPE(1-267) (generously supplied by B.A. Spruce) (Spruce et al. 1988) into plasmid pGEM-1 (Promega, Madison, WI) between BamHIHindIII sites. The plasmid was linearized with EcoRI or HindIII for transcription of sense and antisense mRNA, respectively.

The transcription mixture included $1 \mu \mathrm{g}$ of linearized template cDNA, $1 \mathrm{mM}$ ATP, $1 \mathrm{mM}$ GTP and $1 \mathrm{mM}$ CTP, $0.65 \mathrm{mM}$ UTP, $0.35 \mathrm{mM}$ DIG-UTP, $10 \mathrm{mM}$ DTT, RNase Inhibitor (2 U/ $\mu$ l of transcription mix), and SP6 or T7 polymerase $(1 \mathrm{U} / \mu \mathrm{l}$ of transcription mix). Transcriptions were carried out at $37^{\circ} \mathrm{C}$ for $2 \mathrm{hrs}$. The DNA templates were then digested by adding 20 units of RNase-free DNase and incubated at $37^{\circ} \mathrm{C}$ for $15 \mathrm{~min}$. The reaction volume was then adjusted to $100 \mu \mathrm{l}$ with $\mathrm{H}_{2} \mathrm{O}$. The riboprobes were hydrolyzed at $60^{\circ} \mathrm{C}$ for 23 min by adding $100 \mu \mathrm{l}$ carbonate buffer $(40 \mathrm{mM}$ sodium bicarbonate $/ 60 \mathrm{mM}$ sodium carbonate). The probes were precipitated with $200 \mu \mathrm{l}$ of $200 \mathrm{mM}$ sodium acetate $/ 1 \%$ acetic acid, $100 \mu \mathrm{g}$ glycogen, plus $600 \mu \mathrm{l}$ cold $100 \%$ ethanol, and centrifuged at $4^{\circ} \mathrm{C}$ for $30 \mathrm{~min}$. The pellets were washed once with $80 \%$ ethanol, dried, and suspended in $\mathrm{H}_{2} \mathrm{O}$.

In Situ Hybridization. Twenty-five micron brain sections were mounted on silane-coated slides (Sigma Chemical Co., St. Louis, MO) and stored at $-80^{\circ} \mathrm{C}$. The sections were thawed at room temperature and fixed in $4 \%$ paraformaldehyde $/ 0.1 \mathrm{M}$ phosphate buffer for 10 $\mathrm{min}$. After fixation the slides were rinsed twice with $0.5 \times$ SSC $(1 \times$ SSC: $0.15 \mathrm{M} \mathrm{NaCl} / 0.015 \mathrm{M} \mathrm{NaCitrate,} 10 \mathrm{~min}$ each), treated with proteinase $\mathrm{K}$ (in $0.5 \mathrm{M} \mathrm{NaCl} / 10 \mathrm{mM}$ Tris, $\mathrm{pH}$ 7.8) for $30 \mathrm{~min}$, and rinsed twice with $0.5 \times$ SSC (10 min each).

The sections were prehybridized for three hours at $42^{\circ} \mathrm{C}$ in hybridization buffer and RNA probes were then added to the sections (400-600 ng per section). The hy- 
bridization buffer contained $50 \%$ formamide, $2 \times$ SSC, $1 \times$ Denhard's Solution, $10 \%$ Dextran Sulfate, $0.5 \mathrm{mg} /$ $\mathrm{ml}$ yeast tRNA, $0.25 \mathrm{mg} / \mathrm{ml}$ salmon sperm DNA, and $0.5 \mathrm{mg} / \mathrm{ml}$ heparin. The hybridizations were carried at $55^{\circ} \mathrm{C}$ overnight in humid chambers which were equili- brated with $50 \%$ formamide $/ 4 \times$ SSC (Paradies and Steward 1997).

Stringency washes were performed as follows: twice in $2 \times \mathrm{SSC} / 1 \mathrm{mM}$ EDTA at $55^{\circ} \mathrm{C}(10 \mathrm{~min}$ each $)$, RNase $(20 \mu \mathrm{g} / \mathrm{ml}$ in $0.5 \mathrm{M} \mathrm{NaCl} / 10 \mathrm{mM}$ Tris, $\mathrm{pH} 8.0)$ at $37^{\circ} \mathrm{C}$
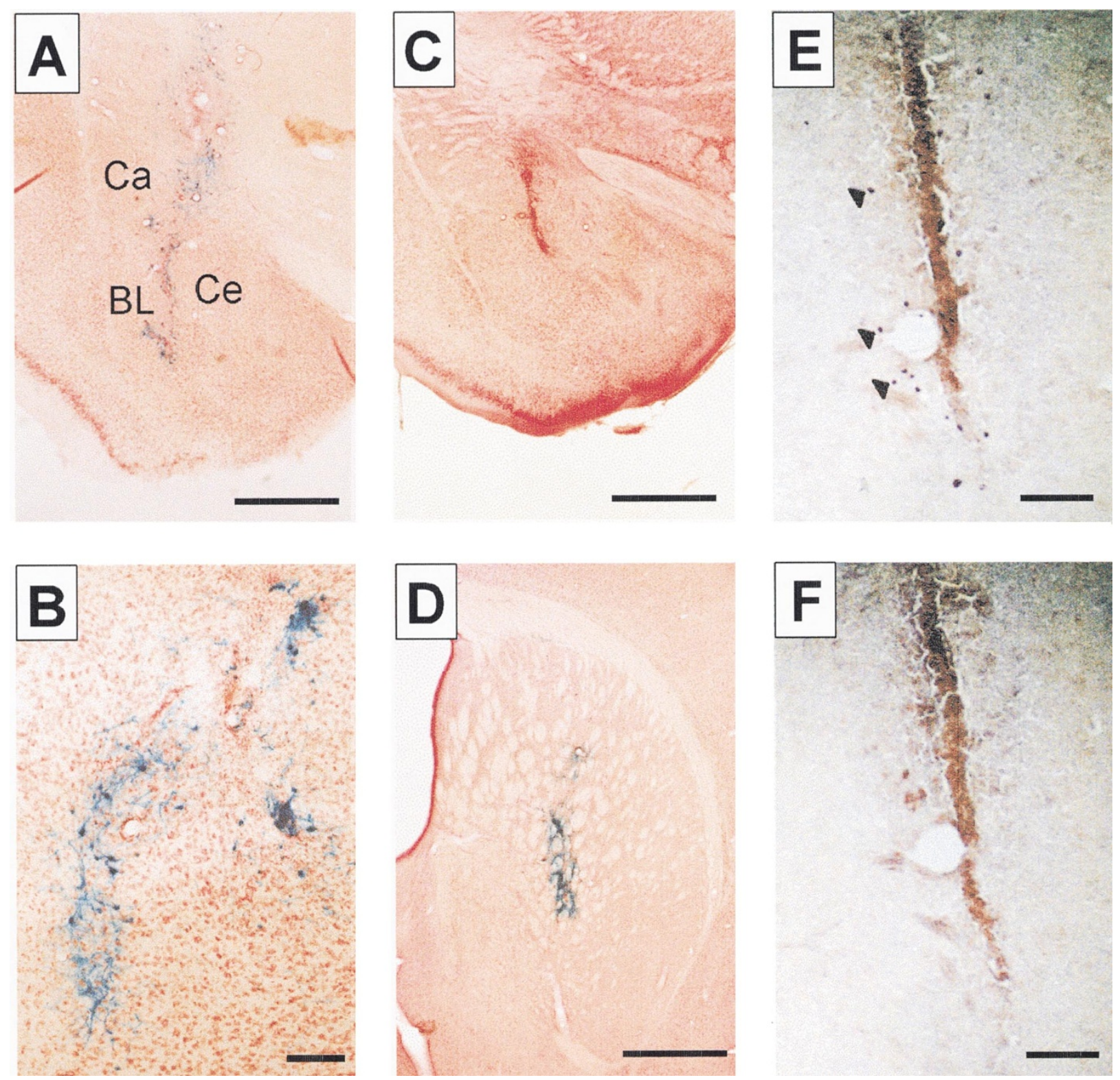

Figure 1. Herpes-mediated gene expression. (A) SHZ.1-induced expression of $\beta$-galactosidase in rat amygdala at three days after infection. (B) Higher magnification of amygdalar $\beta$-galactosidase expression seen in panel A. (C) SHZ.1-induced expression of $\beta$-galactosidase in rat amygdala at nine days after infection. Note the location of the needle tract, but the lack of $\beta$-galactosidase expression. (D) SHZ.1-induced expression of $\beta$-galactosidase in rat caudate at three days after infection. For Panels A-D, coronal sections $(50 \mu \mathrm{M})$ of paraformaldehyde-fixed brains were reacted with X-Gal and counterstained with neutral red. (E) and (F) SHPE-induced expression of hPPE mRNA. Coronal sections (25 $\mu$ M) of paraformaldehyde-fixed brains were taken two days after infection with SHPE and hybridized with digoxigenin-labeled human preproenkephalin specific mRNA probes. Adjacent sections from the same rat brain hybridized with human preproenkephalin mRNA antisense $(\mathrm{E})$ or sense $(\mathrm{F})$ probes, respectively. The arrowheads in Panel E indicate cells expressing the human preproenkephalin mRNA. Bars in Panels A, C, and D represent $1 \mathrm{~mm}$, and bars in Panels B, E, and F represent 0.1 mm. Abbreviations: Ce, central amygdala; BL, basolateral amygdala; $\mathrm{Ca}$, caudate. 
for $30 \mathrm{~min}$, twice in $2 \times \mathrm{SSC} / 1 \mathrm{mM}$ EDTA at $55^{\circ} \mathrm{C}(10$ min each), twice in $0.1 \times \mathrm{SSC} / 1 \mathrm{mM}$ EDTA at $65^{\circ} \mathrm{C}(15$ min each), and twice in $0.5 \times \mathrm{SSC}$ at $55^{\circ} \mathrm{C}(10 \mathrm{~min}$ each).

Digoxigenin immunohistochemical staining was performed as follows: slides were rinsed three times with TBS (400 mM NaCl/100 mM Tris, pH 7.5, 10 min each), blocked with $1 \%$ BSA $/ 0.2 \%$ Triton X-100 in TBS for $1 \mathrm{hr}$, incubated with anti-digoxigenin Fab fragments (1:1000 dilution) conjugated to alkaline phosphatase (Boehringer Mannheim, Indianapolis, IN), rinsed twice with TBS (10 min each), and equilibrated once with NMT (0.1 M $\mathrm{NaCl} / 50 \mathrm{mM} \mathrm{MgCl}$ in $0.1 \mathrm{M}$ Tris, $\mathrm{pH}$ 9.5). The sections were then immersed overnight in colonization solution (3-Nitro Blue Tetrazolium salt $4.5 \mu \mathrm{l} / \mathrm{ml}$ NMT, 5-bromo4-chloro-3-indolyl phosphate $3.5 \mu \mathrm{l} / \mathrm{ml}$ NMT; Boehringer Mannheim, Indianapolis, IN) at $4^{\circ} \mathrm{C}$. The reaction was quenched by rinsing slides in $0.1 \mathrm{M}$ Tris, $\mathrm{pH}$ 8.5.

\section{RESULTS}

\section{Herpes-mediated Gene Expression}

Histochemical analysis confirmed the virus-mediated transgene expression. As seen in Figures $1 \mathrm{~A}$ and $1 \mathrm{~B}$, strong expression of $\beta$-galactosidase was seen in the first 2-4 days after SHZ.1 infection and declined thereafter, with little or no expression after one week (Figure $1 \mathrm{C}$ shows nine-day time point). The time course of this marker gene expression is similar to that observed in other studies (Glorioso et al. 1995).

In rats infected with SHPE, human preproenkephalin mRNA expression peaked around day 2 (Figure 1E). While most of the infected cells were localized around injection sites, a few were also found along the needle tract. The target area for injection was the border between the central and basolateral nucleus, and anatomical analysis revealed that gene expression was predominantly in the central nucleus of the amygdala with some spread into basolateral region (see Figure 1A). The infected areas usually spread 1-1.5 mm around the injection site in the dorsal-ventral and anterior-posterior directions, but were much more limited in the medial-lateral direction.

Although expression of the SHZ.1 virus (Figures 1A and $1 \mathrm{~B}$ ) appeared more intense than SHPE mRNA expression (Figure 1E), visual analysis of the number of cell bodies infected revealed that similar numbers of neurons were infected using both procedures. The difference in apparent intensity is due to histochemical staining of $\beta$-galactosidase throughout the neuronal cell body and processes, as well as the use of thicker sections for this procedure compared with in situ hybridization (50 versus 25 microns).Virusinfected animals showed no overt behavioral or neurological abnormalities, and microscopic inspection of stained sections indicated neural damage from the viral infection was minimal. Although infected animals lost some body weight immediately following stereotaxic surgery, food consumption, water intake, and normal grooming behavior suggested that the general health of the animals was not adversely affected by the viral infection.

\section{Potentiation of the Anxiolytic Effect of Diazepam by SHPE Infection in the Amygdala}

A significant interaction between diazepam treatment and SHPE infection in the amygdala was seen in open arm exploration, as indicated by increases of percent
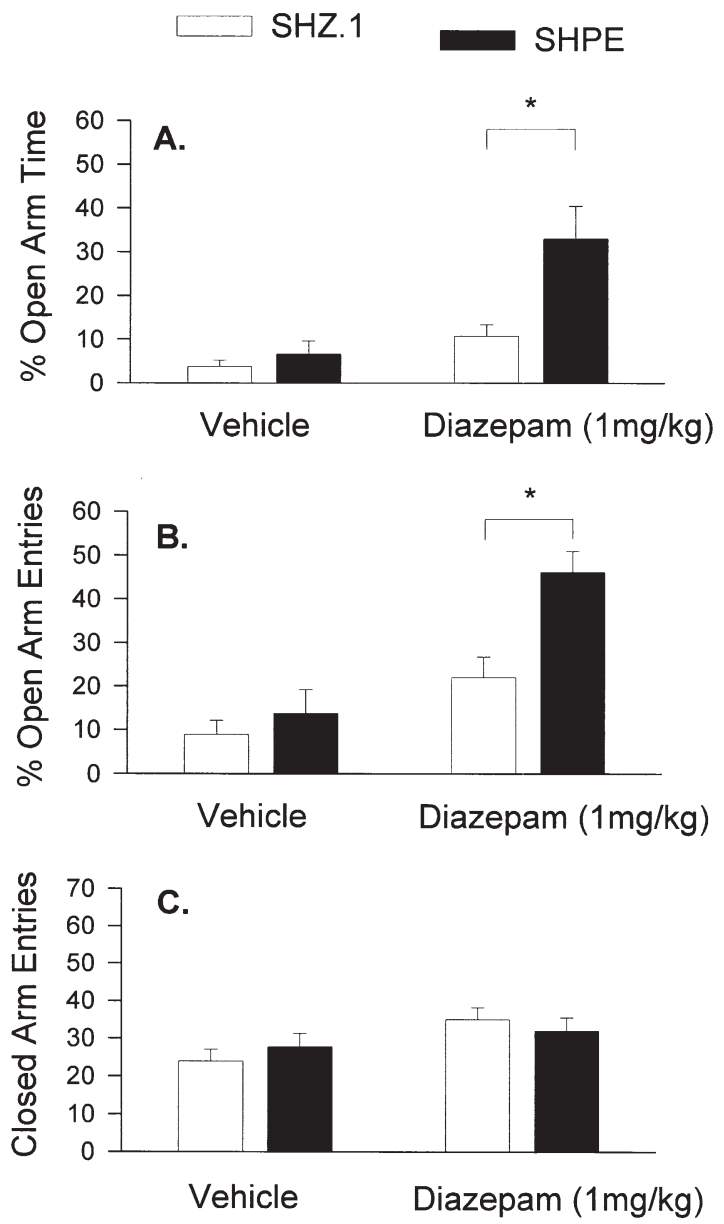

Figure 2. Potentiation of the anxiolytic effect of diazepam by SHPE-infection in the amygdala. Rats were infected with SHPE or SHZ.1 virus in the amygdala, and elevated plus maze tests were conducted three days after infection. Thirty minutes prior to testing, animals received either vehicle or diazepam $(1 \mathrm{mg} /$ $\mathrm{kg}$, i.p.). The plus maze performance is presented as percent open arm time (A) percent open arm entries (B) and number of closed arm entries (C). Values represent mean \pm standard error of the mean (S.E.M.) of 10-11 rats in each group. * significantly different from SHZ.1-infected animals. In Panel A, diazepam induced a significant increase of open arm time in SHPEinfected animals, and the response to diazepam was significantly higher in rats infected with SHPE compared to those infected with SHZ.1. Percent open arm entries showed similar results. 
open arm time and open arm entries (Figures 2A and 2B), with SHPE infection in the amygdala significantly increasing the anxiolytic effects of diazepam treatment. As seen in Figure 2A, the percent open arm time was not significantly different between animals infected with SHPE and SHZ.1 that received a vehicle injection before testing. However, the increase of open arm time induced by diazepam injection was much greater in SHPE-infected animals, compared to SHZ.1-infected animals (Figure 2A) and animals receiving an intraamygdala injection of vehicle (data not shown). Twoway ANOVA revealed an interaction between SHPE infection and diazepam treatment $\left(\mathrm{F}_{1,37}=5.5 ; p<.05\right)$ for percent open arm time.

Following diazepam treatment rats infected with SHPE spent a significantly greater percentage of time in the open arm compared to those infected with SHZ.1 $(t(18)=3.7, p<.01)$ and SHPE-infected animals receiving a vehicle injection $(t(18)=4.4, p<.001)$. Percent open arm entries, an anxiety measure that factors out the activity level, showed similar results (Figure 2B), with ANOVA revealing a significant interaction between virus and diazepam treatments $\left(\mathrm{F}_{1,37}=4.5, p<.05\right)$.

The locomotor activity, as indicated by total closed arm entries, was not affected by viral infection (Figure $2 \mathrm{C} ; \mathrm{F}_{1,37}=0.01$ and $\mathrm{F}_{1,37}=1.1$ for interaction, $p>.1$ ). The enhancement in locomotor activity measures following low doses of diazepam is similar to previous results from our laboratory $\left(\mathrm{F}_{1,37}=5, p<.03\right.$ for diazepam effect). Time in the center square did not differ between treatment groups, with values of $22 \pm 5,20 \pm 4,23 \pm 6$, and $36 \pm 8$ mean \pm S.E.M. seconds spent in the center in the SHZ.1-Vehicle, SHZ.1-diazepam, SHPE-Vehicle, and SHPE-diazepam groups, respectively $\left(\mathrm{F}_{1,37}=2\right.$ for virus effect, $\mathrm{F}_{1,37}=1$ for diazepam effect, and $\mathrm{F}_{1,37}=1.5$ for interaction, $p>.05)$. Thus, animals spent more than $95 \%$ of the trial exploring the arms of the maze, although 8 of the 41 rats had zero values of percent open arm time or entries (during the $10 \mathrm{~min}$ trial). This low baseline level of open arm time was seen predominantly ( 7 of the 8 ) in two of the 10 batches of rats tested during these experiments, and were distributed throughout the SHZ.1 and SHPE-Vehicle groups (no zero open arm times were observed in the SHPE-diazepam treated groups). These results suggest expressing preproenkephalin in the amygdala greatly enhanced the anxiety-reducing effect of diazepam.

Although upon initial maze exposure five and ten minute trial times yield similar results (File et al. 1993), behavioral measures were also analyzed for the first 5 min of the 10-min test. Analysis of the first 5-min period of maze exposure showed a similar enhancement of the anxiolytic influences of diazepam in the elevated plus maze, as indicated by increased percent open arm time and percent open arm entries. Percent open arm times were $6 \pm 2 \%$ and $13 \pm 6 \%$ for SHZ.1 and SHPE vehicle groups, and $22 \pm 5 \%$ vs. $42 \pm 7 \%$ for SHZ. 1 and SHPE diazepam-treated rats, respectively. Percent open arm entries were $11 \pm 4 \%$ and $17 \pm 7 \%$ for SHZ. 1 and SHPE vehicle groups, and $25 \pm 5 \%$ vs. $49 \pm 4 \%$ for SHZ.1 and SHPE diazepam-treated rats. Significant main effects of virus $\left(F_{1,37}=7\right.$ for open arm time, $F_{1,37}=9$ for open arm entries, $p<.02)$ and diazepam $\left(\mathrm{F}_{1,37}=20\right.$ for open arm time and entries, $p<.0001$ ) were observed, although the interaction terms were marginal $\left(\mathrm{F}_{1,37}=3, p=.09\right)$. Post-hoc $t$-tests demonstrated that SHPE diazepamtreated rats differed from SHPE-vehicle groups for open arm time, while open arm entries of this group differed from both SHPE-vehicle groups and SHZ.1 diazepam-treated groups. This supports other work from our laboratory indicating that similar results are observed using both a five and ten minute trial period upon initial exposure to the maze.

\section{Response to Diazepam Was Not Altered Following SHPE Infection in the Caudate}

To examine the regional specificity of this potentiated diazepam effect, additional rats were infected bilaterally with either SHPE or SHZ.1 in the caudate nucleus (see Figure 1D). As shown in Figure 3A, the responses to diazepam were not affected by SHPE infection. Neither open arm time nor open arm entries (data not shown) differed between groups infected with SHPE and SHZ.1 in the caudate nucleus. These results indicate the potentiation of the anxiolytic effect of diazepam by SHPE was amygdala-specific.

\section{The Enhanced Diazepam Action was Dependent on Preproenkephalin Gene Expression}

Since transgene expression dissipated after one week, we examined the responses to diazepam in rats infected with either SHPE or SHZ.1 in the amygdala in the elevated plus maze test nine days after infection. The open arm time (Figure 3B) or open arm entries (data not shown) following diazepam injection no longer differed between rats infected with SHPE and those infected with SHZ.1. The closed arm entries remained unchanged. The results suggest the change in diazepam responses was due to SHPE-mediated expression of preproenkephalin, rather than nonspecific effects of viral infection.

\section{SHPE-Induced Enhancement of Diazepam Effect was Blocked by Naloxone}

To insure an opioid-dependent mechanism was involved in this potentiated diazepam action, rats infected with either SHPE or SHZ.1 in the amygdala received intraperitoneal injections of the opioid antagonist naloxone hydrochloride $(5 \mathrm{mg} / \mathrm{kg}$ ) with diazepam (1 $\mathrm{mg} / \mathrm{kg}) 30 \mathrm{~min}$ before testing. The opioid antagonist 

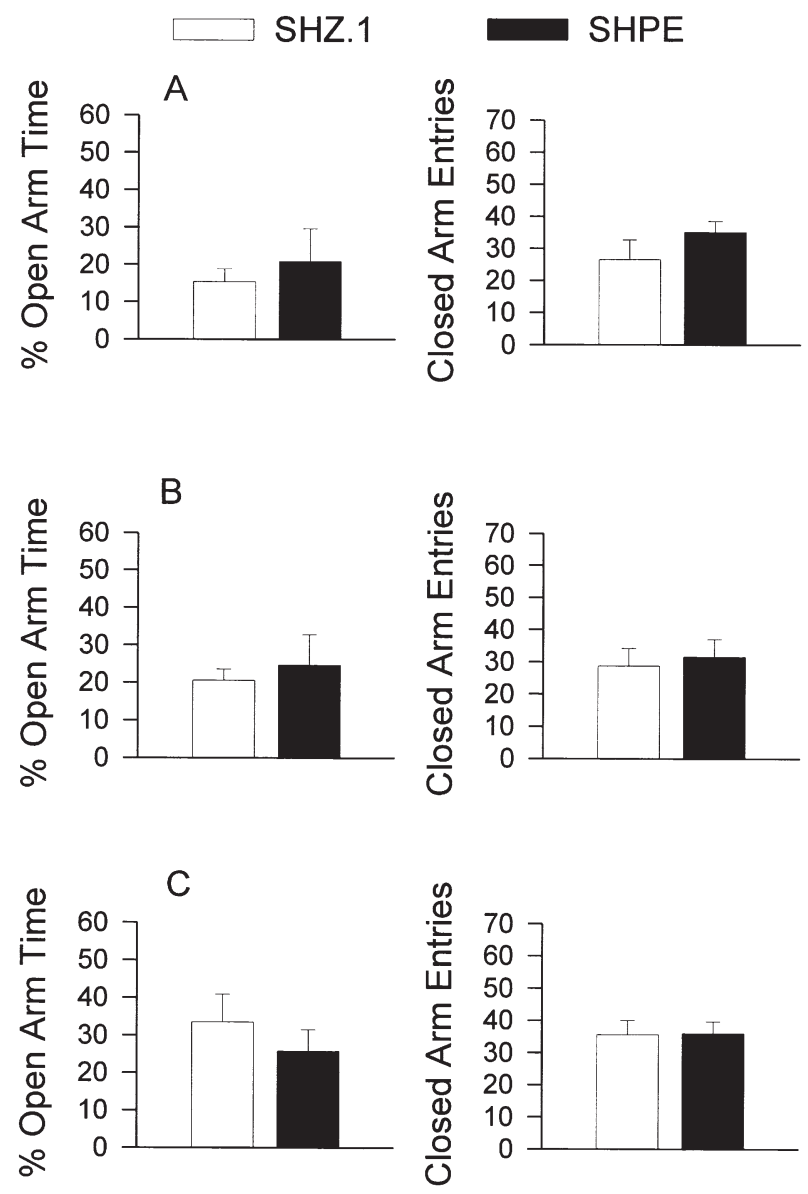

Figure 3. Characterization of the response to diazepam following SHPE infection. All animals received diazepam injection $(1 \mathrm{mg} / \mathrm{kg}$, i.p.) $30 \mathrm{~min}$ before testing to examine the responses to diazepam. The elevated plus maze performance was presented as percent open arm time (left, Panels A, B, and C) and closed arm entries (right, Panels A, B, and C). Values represent mean \pm S.E.M. of $6-8$ rats in each group, with direct comparisons between viral constructs in each experiment conducted with student $t$-tests $\left({ }^{*} p<.05\right)$. (A) Response to diazepam following viral infection in the caudate. Rats were infected with SHPE $(n=6)$ or SHZ.1 $(n=$ 8 ) virus in the caudate nucleus and tested for their responses to diazepam in the elevated plus maze 3 days after infection. (B) Response to diazepam nine days after viral infection. Rats were infected with SHPE $(n=8)$ or SHZ.1 $(n=8)$ virus in the amygdala and tested for their responses to diazepam in the elevated plus maze nine days after the infection. (C) The enhancement of diazepam effect by SHPE infection in the amygdala was blocked by naloxone. Rats were infected with SHPE $(n=8)$ or SHZ.1 $(n=6)$ virus in the amygdala and tested three days later in the elevated plus maze. Naloxone (5 mg/kg, i.p.) and diazepam (1 mg/kg, i.p.) were injected $30 \mathrm{~min}$ before testing.

abolished the differences in diazepam responses between SHPE- and SHZ.1-infected groups (Figure 3C). Similar results were observed when data was analyzed during the first $5 \mathrm{~min}$ trial. This result indicates the po-

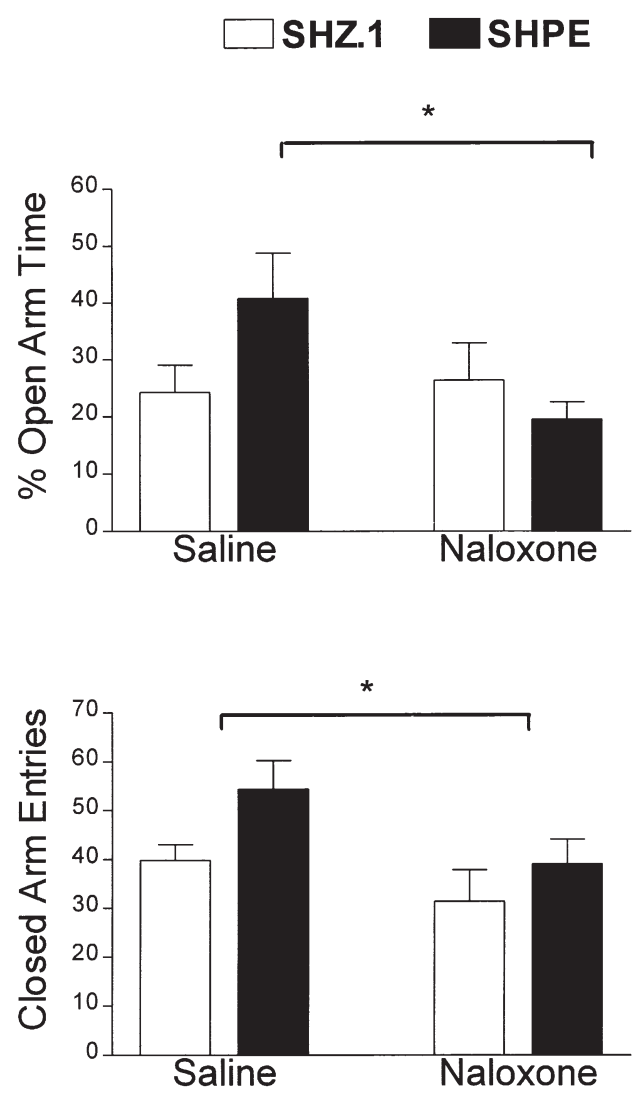

Figure 4. Effects of SHPE reversed by the opioid antagonist naloxone. Rats were infected with SHPE or SHZ.1 virus in the amygdala and tested three days later in the elevated plus maze. Naloxone (5 mg/kg, i.p.) or vehicle (saline, i.p.), plus diazepam (1 mg/kg, i.p.) were injected $30 \mathrm{~min}$ before testing in all animals. One animal in each of the four groups was tested concurrently. The elevated plus maze performance was presented as percent open arm time (top) and closed arm entries (bottom). For percent open arm time, ANOVA indicated a significant difference between groups, with post-hoc tests indicating SHPE rats receiving saline had higher percent open time than SHPE rats receiving naloxone. For closed arm entries (Panel B), naloxone decreased this measure of activity, while SHPE infected animals showed a slightly higher level of closed arm entries than SHZ.1 infected groups. There was no interaction, however, between viral infection and naloxone treatment. Values represent mean \pm S.E.M. of $8,10,9$, and 8 rats in each group (from left to right), and ${ }^{*} p<.05$.

tentiation of the anxiolytic effect of diazepam by SHPE was mediated by an opioid receptor mechanism.

Although this initial naloxone study indicated that no difference was observed between SHPE or SHZ.1infected groups, the mean level of open-arm time in SHZ.1 diazepam-treated animals (see Figure 3C) was higher than that observed during our initial studies (Figure 1A). Since the influences of systemically administered naloxone on the anxiolytic actions of diazepam in 


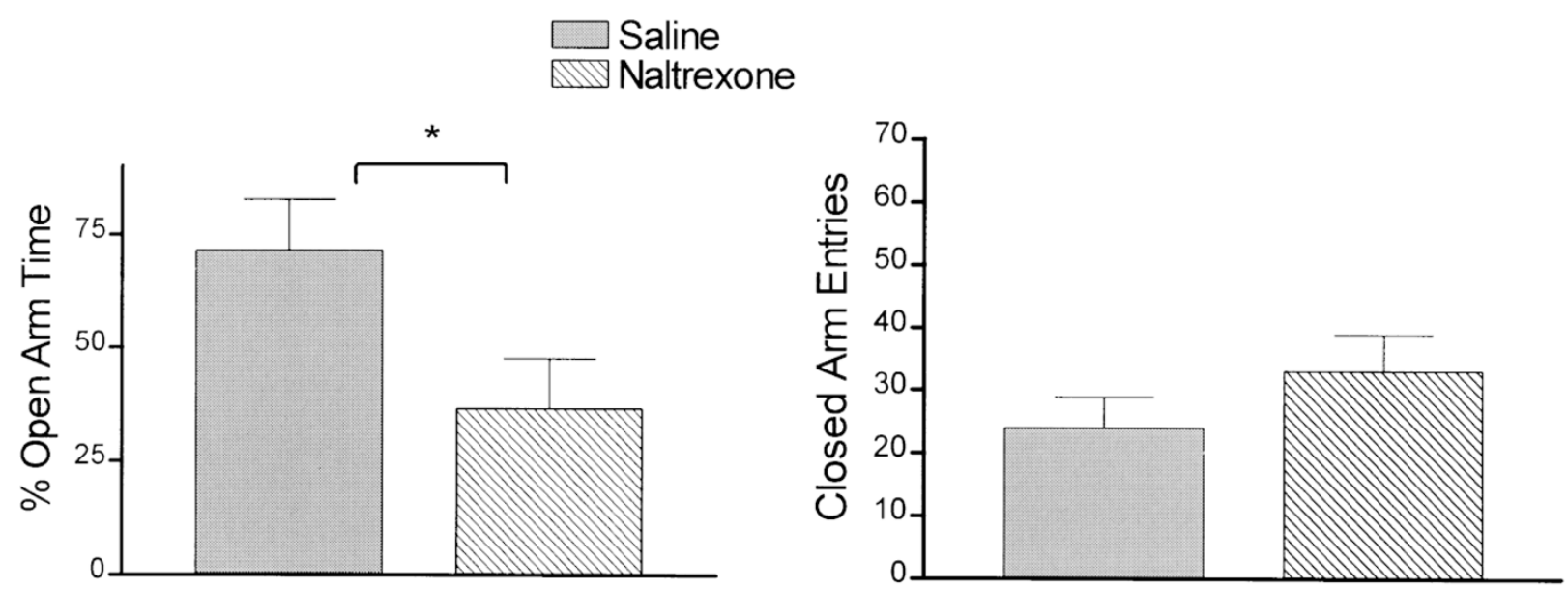

Figure 5. Effects of local naltrexone in amygdala on anxiolytic effects of diazepam. Non-infected rats received bilateral injections of naltrexone ( $20 \mu \mathrm{g}$ in $1 \mu \mathrm{l}$ of saline; $n=6)$ or saline $(n=7)$ into the amygdala through indwelling cannula just prior administration of diazepam ( $2 \mathrm{mg} / \mathrm{kg}$, i.p.). Thirty minutes later animals were tested on the elevated plus maze. Open arm time (Left Panel) and closed arm entries (Right Panel) showed that this opioid antagonist administered locally in amygdala attenuated the anxiety-reducing influences of diazepam, as demonstrated by a reduction in percent open arm time. Closed-arm activity was not affected by naltrexone administration. Values represent mean \pm S.E.M. ${ }^{*}$ indicates significantly different $(p<.05)$ from saline animals.

the elevated plus maze appear variable (see Agmo et al. 1995, below), an additional naloxone reversal study was performed. Rats received either SHPE or SHZ.1 in the amygdala. Three days later rats received the opioid antagonist naloxone hydrochloride $(5 \mathrm{mg} / \mathrm{kg}$, i.p.) or saline, along with diazepam $(1 \mathrm{mg} / \mathrm{kg}) 30 \mathrm{~min}$ before testing. The results in Figure 4 show that SHPE-infected group showed an increased anxiolytic action of diazepam (cf Figure 2) compared to SHPE-naloxone treated groups $\left(\mathrm{F}_{3,52}=2.7, p=.05\right.$ for ANOVA on percent open arm time).

Naloxone administration had no effect on open arm time or entries in SHZ.1 infected groups. In both SHZ.1 and SHPE groups, naloxone administration decreased closed arm entries, suggesting a decrease in activity which was independent of viral construct (see Figure 4) $\left(\mathrm{F}_{1,31}=4.6 ; p<.04\right)$. SHPE infection also enhanced closed arm entries slightly $\left(\mathrm{F}_{1,31}=4, p=.05\right)$, but center square time was not affected by naloxone injection or viral infection (data not shown). These results support the notion that SHPE infection in amygdala potentiates the anxiolytic effects of diazepam, and that this effect is naloxone-reversible.

\section{Naltrexone Administration in Amygdala Attenuates the Anxiolytic Actions of Diazepam}

To further test the notion that amygdalar opioid peptides play some role in the anxiolytic actions of diazepam, the opioid antagonist naltrexone was microinjected into the amygdala of non-infected rats just prior to the systemic administration of an effective dose of diazepam $(2.0 \mathrm{mg} / \mathrm{kg}$, i.p.). As seen in Figure 5, local ad- ministration of naltrexone [20 $\mu \mathrm{g}$; dose based on Kelley et al. (1996)] in the amygdala significantly attenuated the anxiolytic actions of diazepam $(t(11)=2.2, p<.05$ for open arm time), but had no effect on activity $(t(11)=$ 0.9 for closed entries, $p=.4$ ). These results from nonvirally infected animals support the suggestion that opioid receptor-mediated events in the amygdala are important in the anxiety-reducing actions of diazepam.

\section{DISCUSSION}

SHPE-mediated expression of preproenkephalin in the rat amygdala increased the behavioral responses to the anxiolytic effects of diazepam in the elevated plus maze test. This effect appeared to be region-specific because it was not found with SHPE infection in the caudate nucleus. The enhanced diazepam action was blocked by the opioid antagonist naloxone and disappeared after gene expression dissipated on day 9, indicating the behavioral changes were mediated by opioid peptides, and were not due to the influences of surgery or viral infection alone.

The findings indicate interactions between opioid peptides and the GABA/benzodiazepine system may play a major role in modulating the anxiolytic actions of benzodiazepines. This is also supported by the ability of the opioid antagonist naltrexone to attenuate the anxiolytic actions of diazepam in non-infected rats. Furthermore, the results demonstrate the importance of the amygdala as a neuroanatomical substrate for the anxiolytic effects of benzodiazepines, since altering a single 
protein in this brain structure caused such a remarkable change in the pharmacological response to diazepam. We have previously shown that transfer of the preproenkephalin gene into amygdala is antinociceptive in the formalin test (Kang et al. 1998). Taken together, these studies demonstrate the use of the herpes-mediated gene transfer technique to evaluate the functions of gene products within specific brain sites in regulating pharmacological responses and complex behaviors.

Although several lines of evidence suggest a strong association between endogenous opioid peptides and the GABA/benzodiazepine system in the brain, the specific mechanisms underlying the ability of preproenkephalin expression in amygdala to enhance the anxiolytic effects of diazepam are unclear. Potentiated diazepam actions could be related to upregulation of GABA/BZ receptors, enhanced allosteric GABA/BZ receptor coupling, and/or increased GABA release induced by enkephalin overexpression in amygdala. GABA and opioid neuropeptides are colocalized in many brain regions, including the central nucleus of amygdala (Roberts 1992; Veinante et al. 1997), and diazepam can modulate opioid peptide release in distinct brain regions (Duka et al. 1979; Wuster et al. 1980). Thus, if the anxiolytic actions of benzodiazepines relies on the release of endogenous opioids, this effect might be potentiated by virus-mediated overexpression of preproenkephalin. Additionally, chronic opioid treatment causes an alteration of GABA/benzodiazepine receptor numbers in the brain (Lopez et al. 1990; Rocha et al. 1993) suggesting potential changes in the GABA/BZ receptor could account for enhanced diazepam effects. Critically testing the involvement of such changes following gene transfer may be difficult due to the potentially small magnitude of effects limited to a confined brain area. Further, there is the possibility that such changes may not be limited to the central regions of amygdala, but may involve enhanced enkephalin release in amygdalar projections.

Studies examining the anatomical localization and neurotransmitter makeup of the neuronal population infected with the virus will also be critical to understanding the mechanism of preproenkephalin-induced increases in diazepam action. This is an important consideration since specific nuclei in the amygdala and in other nearby brain regions appear to play differing roles in various models of anxiety and effects of anxiolytics (Pesold and Treit 1995; Gonzalez et al. 1996; Davis et al. 1997; Moller et al. 1997).

Many neurons in the central amygdala express neuropeptides including enkephalin (see Petrovich and Swanson 1997; Honkaniemi et al. 1992), and it is currently unclear if neurons expressing human preproenkephalin are normally enkephalinergic, or if opioid peptides have been added to their neurotransmitter repertoire. Moreover, neurons of the lateral region of the central nucleus have strong projections to the medial portion of the central nucleus, as well as the parabrachial nucleus and the bed nucleus of the stria terminalis (Petrovich and Swanson 1997). This lateral region is generally part of the amygdalar region affected by the infection, suggesting that enkephalin overexpression could be modifying these intra-amygdalar circuits. The results, at the very least, suggest that the infected amygdalar neurons are part of a neural circuit that can influence the anxiolytic actions of benzodiazepines. One advantage of this gene transfer methodology, compared with microinjection studies, is that the altered neuropeptide must be packaged, processed and released during a behavioral task, otherwise altered gene expression would not affect pharmacological responses. In contrast, microinjection of opioids into this region might activate receptors and modify circuits which can alter benzodiazepine actions, but are not critically involved in responses to these drugs.

Systemically administered naloxone abolished the enhanced effects of induced by SHPE, although naloxone alone did not modify diazepam responses in SHZ.1-infected animals. While others have found that opioid antagonists have no intrinsic effects on anxietylike behaviors, a few reports show an anxiogenic action of opioid antagonists in the social interaction test and conflict paradigm (Agmo et al. 1995; Tsuda et al. 1996; Zhang et al. 1996). Opioid antagonists have been shown to block the anxiolytic or anti-conflict effects of benzodiazepines in humans and laboratory animals (Billingsley and Kubena 1978; Koob et al. 1980; Duka et al. 1981, 1982; Agmo et al. 1995; Tsuda et al. 1996), although some reports fail to show influences of opioid antagonists on the anticonflict properties of benzodiazepines (Britton et al. 1981). The underlying mechanisms and site of action for these effects remain unknown. In contrast, systemically-administered naloxone potentiates the anxiolytic action of sub-effective doses of benzodiazepines and buspirone (Belzung and Agmo 1997), suggesting that the influences of opioids may depend on the dose or type of benzodiazepine administered or the test of anxiety-like behavior. The apparently contradictory influences of opioid agonists (preproenkephalin overexpression) and antagonists (systemic naloxone) (Belzung and Agmo 1997) in this task, while both indicating opioid involvement, may also be related to the local versus systemic modulation of opioid actions. This is supported by the ability of locally administered naltrexone in the amygdala to attenuate the anxiolytic actions of systemically administered diazepam. Further studies will be needed to assess if this dose of naltrexone may have affected opioid processes by spread into additional areas and/or induced anxiogenic-like effects on its own. These studies, however, suggest this method of locally manipulating endogenous opioid release in confined brain regions may help elucidate the 
role of opioids in select brain regions in modifying anxiety-like behaviors and responses to anxiolytics using other models of anxiety.

Transfer of the preproenkephalin cDNA into the amygdala selectively increased the response to the anxiolytic effect of diazepam. Closed arm entries, which are an indicator of locomotor activity, remained unaffected by various treatments among all the groups or were similarly affected by viral infection with SHZ.1 or SHPE (cf. Figure 4). Similar center times were also observed. Systemic diazepam administration produces anxiolytic actions in the elevated plus maze test as well as many other behavioral tests, and doses ranging from 2 to $5 \mathrm{mg} / \mathrm{kg}$ are often used (also see saline group in Figure 5). In our study, $1 \mathrm{mg} / \mathrm{kg}$ diazepam (given 30 min before testing) did not produce a significant effect in SHZ.1-infected animals or sham-injected animals, supporting the notion that this is a sub-effective dose in this behavioral test (Agmo et al. 1995; Griebel et al. 1996). Although analysis of the first five minute trial produced a greater apparent effect of diazepam on measures of anxiolytic behavior in SHZ.1 infected animals, both the five and ten minute analysis of plus maze data demonstrated that SHPE infection in the amygdala enhances the anxiety-related influences of diazepam in the plus maze task.

These studies demonstrate that both the transgene expression and the behavioral changes induced by herpes virus-mediated gene transfer were transient, peaking at $2-4$ days after infection and dissipating by 7-9 days after injection in the amygdala. There were no apparent behavioral abnormalities following infection, and microscopic analysis did not demonstrate signs of neuronal damage. Similar responses to diazepam were observed in both SHZ.1-infected and vehicle-injected animals, suggesting these effects are not related to consequences of viral infection alone. The short post-operative recovery time may have contributed to the lower open arm activity in rats tested on day 3 compared to those tested on day 9, although other factors (batches of animals or viral preparations) may have also contributed to the alterations in baseline responding in the SHZ.1-infected groups tested at these two time points. Although modifying the viral construct to achieve longterm expression would be beneficial for future studies, the transient nature of transgene expression will also allow re-testing of infected animals after viral expression has waned (as in Carlezon et al. 1997).

In summary, the current findings demonstrate that expressing opioid peptides in the amygdala potentiated the anxiolytic effects of benzodiazepines. The fact that naloxone was able to block this potentiation suggests the effect is mediated by SHPE-induced increase of opioid peptides, the release of which is most likely triggered by the injection of diazepam. The ability of herpes virusmediated gene transfer to alter preproenkephalin in en- dogenous neural circuits could help elucidate opioidbenzodiazepine interactions and the role of opioid systems in various benzodiazepine actions. The effects of virus-mediated expression of preproenkephalin on other benzodiazepine effects, and on the anxiety-reducing actions in other animal models, may elucidate the mechanism underlying this opioid-mediated enhancement of benzodiazepine anxiolytic action.

\section{ACKNOWLEDGMENTS}

The authors thank Drs. J.C. Glorioso and M.A. Bender for recombinant virus generation and supplying 7B cells, Drs. F. Liu and P.R. Housley for construction of the pGEMhPPE plasmid, Drs. M. Paradies and O. Steward for help with in situ hybridization, Dr. H. Stock for assistance in behavioral testing, and Kris Ford and Taryn Jackson for expert technical assistance. This work was supported by NIH RO1 DA05932, KO2 00249, and RO3MH59865 to MAW, the USC School of Medicine Research Development Fund and the Carolina Venture Fund to MAW and SPW.

\section{REFERENCES}

Agmo A, Galvan A, Heredia A, Morales M (1995): Naloxone blocks the antianxiety but not the motor effects of benzodiazepines and pentobarbital: Experimental studies and literature review. Psychopharmacology 120:186194

Belzung C, Agmo A (1997): Naloxone potentiates the effects of subeffective doses of anxiolytic agents in mice. Eur J Pharmacol 323:133-136

Billingsley ML, Kubena RK (1978): The effects of naloxone and picrotoxin on the sedative and anticonflict effects of benzodiazepines. Life Sci 22:897-906

Britton DR, Britton KT, Dalton D, Vale W (1981): Effects of naloxone on anti-conflict and hyperphagic actions of diazepam. Life Sci 29:1297-1302

Carlezon WA Jr, Broundy VA, Haile CN, Lane SB, Kalb RG, Neve RL, Nester EJ (1997): Sensitization to morphine induced by viral-mediated gene transfer. Science 277:812-814

Cooper SJ (1983): Benzodiazepine-opiate antagonist interactions in relation to feeding and drinking behavior. Life Sci 32:1043-1051

Darke S, Swift W, Hall W, Ross M (1993): Drug use, HIV risk-taking and psychosocial correlates of benzodiazepines use among methadone maintenance clients. Drug Alcohol Depend 34:67-70

Davis M, Walker DL, Lee Y (1997): Amygdala and bed nucleus of the stria terminalis-differential roles in fear and anxiety measured with the acoustic startle reflex. Phil. Trans. Royal Soc. London-Series B: Biol Sci 352:1675-1687

Davis M, Rainnie D, Cassell M (1994): Neurotransmission in the rat amygdala related to fear and anxiety. TINS $17: 208-214$

Dobson AT, Margolis TP, Sedarati F, Stevens JG, Feldman 
LT (1990): A latent, nonpathogenic HSV-1-derived vector stably expresses $\beta$-galactosidase in mouse neurons. Neuron 5:353-360

Duka T, Cumin R, Haefely W, Herz A (1981): Naloxone blocks the effect of diazepam and meprobamate on conflict behaviour in rats. Pharm Biochem Behav 15:115-117

Duka T, Wuster M, Herz A (1979): Rapid changes in enkephalin levels in rat striatum and hypothalamus induced by diazepam. Naunyn Schmiedebergs Arch Pharmacol 309:1-5

Duka T, Millan MJ, Ulsamer B, Doenicke A (1982): Naloxone attenuates the anxiolytic action of diazepam in man. Life Sci 31:1833-1836

File SE, Rodgers RJ (1979): Partial anxiolytic action of morphine sulphate following microinjection into the central nucleus of the amygdala in rats. Pharm Biochem Behav 11:313-318

File SE, Zangrossi H, Viana M, Graeff FG (1993): Trial 2 in the elevated plus-maze: A different form of fear. Psychopharmacology 111:491-494

Glorioso JC, DeLuca NA, Fink DJ (1995): Development and application of herpes simplex virus vectors for human gene therapy. Ann Rev Microbiol 49:675-710

Gonzalez LE, Andrews N, File SE (1996): 5-HT1a and benzodiazepine receptors in the basolateral amygdala modulate anxiety in the social interaction test, but not in the elevated plus-maze. Brain Res 732:145-153

Good AJ, Westbrook RF (1995): Effects of a microinjection of morphine into the amygdala on the acquisition and expression of conditioned fear and hypoalgesia in rats. Behav Neurosci 109:631-641

Griebel G, Sanger DJ, Perrault G (1996): The use of the rat elevated plus-maze to discriminate between non-selective and BZ-1 (omega 1) selective, benzodiazepine receptor ligands. Psychopharmacology 124:245-254

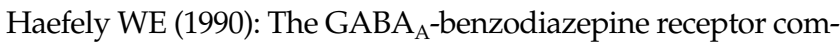
plex and anxiety. In Sartorius N, Andreoli V, Cassano G, Eisenberg L, Kielholz P, Pancheri P, Racagni G (eds), Anxiety. Psychobiological and Clinical Perspectives. New York, Hemisphere Publishing Corporation, pp 23-36

Honkaniemi J, Pelto-Huikko M, Rechardt L, Isola J, Lammi A, Fuxe K, Gustafsson JA, Wikstrom A-C, Hokfelt T (1992): Colocalization of peptide and glucocorticoid receptor immunoreativities in rat central amygdaloid nucleus. Neuroendocrinology 55:451-459

Kang W, Wilson MA, Bender MA, Glorioso JC, Wilson SP (1998): Herpes virus-mediated preproenkephalin gene transfer to the amygdala is antinociceptive. Brain Res 792:133-135

Kelley AE, Bless EP, Swanson CJ (1996): Investigation of the effects of opiate antagonists infused into the nucleus accumbens on feeding and sucrose drinking in rats. J Pharmacol Exp Ther 278:1499-1507

Konig M, Zimmer AM, Steiner H, Holmes PV, Crawley JN, Brownstein MJ, Zimmer A (1996): Pain responses, anxiety and aggression in mice deficient in pre-proenkephalin. Nature (Lond) 383:535-538

Koob GF, Strecker RE, Bloom FE (1980): Effects of naloxone on the anticonflict properties of alcohol and chlordiazepoxide. Subst Alcohol Actions Misuse 1:447-457

Lopez F, Miller LG, Thompson ML, Schatzki A, Chesley S,
Greenblatt DJ, Shader RI (1990): Chronic morphine administration augments benzodiazepine binding and GABA receptor function. Psychopharmacology 101:545-549

Loughlin SE, Leslie FM, Fallon JH (1995): Endogenous opioid systems. In Paxinos G (ed), The Rat Nervous System. San Diego, CA, Academic Press, Inc., pp 975-1001

McGaugh JL, Cahill L, Roozendaal B (1996): Involvement of the amygdala in memory storage: Interaction with other brain systems. Proc Natl Acad Sci USA 93:13508-13514

Mester JC, Pitha PM, Glorioso JC (1995): Antiviral activity of herpes simplex virus vectors expressing murine $\alpha 1$-interferon. Gene Ther 2:187-196

Millan MJ, Duka T (1981): Anxiolytic properties of opiates and endogenous opioid peptides and their relationship to the actions of benzodiazepines. Mod Probl Pharmacopsychiatry 17:123-141

Moller C, Wiklund L, Sommer W, Thorsell A, Heilig M (1997): Decreased experimental anxiety and voluntary ethanol consumption in rats following central but not basolateral amygdala lesions. Brain Res 760:94-101

Nowakowska E, Chodera A (1990): Studies on the involvement of opioid mechanism in the locomotor effects of benzodiazepines in rats. Pharm Biochem Behav 38:265-266

Olson GA, Olson RD, Kastin AJ (1996): Endogenous opiates, 1995. Peptides 17:1421-1466

Paradies MA, Steward O (1997): Multiple subcellular mRNA distribution patterns in neurons: A nonisotopic in situ hybridization analysis. J Neurobiol 33:473-493

Paxinos G, Watson C (1997): The Rat Brain in Stereotaxic Coordinates. San Diego, Academic Press, Inc.

Pellow S, Chopin P, File SE, Briley M (1985): Validation of open:closed arm entries in an elevated plus-maze as a measure of anxiety in the rat. J Neurosci Meth 14:149-167

Pesold C, Treit D (1994): The septum and amygdala differentially mediate the anxiolytic effects of benzodiazepines. Brain Res 638:295-301

Pesold C, Treit D (1995): The central and basolateral amygdala differentially mediate the anxiolytic effects of benzodiazepines. Brain Res 671:213-21

Petersen EN, Braestrup C, Scheel-Kruger J (1985): Evidence that the anticonflict effect of midazolam in the amygdala is mediated by the specific benzodiazepine receptors. Neurosci Lett 53:285-288

Petrovich GD, Swanson LW (1997): Projections from the lateral part of the central amygdalar nucleus to the postulated fear conditioning circuit. Brain Res 763:247-254

Privette T, Terrian DM (1995): Kappa opioid agonists produce anxiolytic-like behavior on the elevated plusmaze. Psychopharmacology (Berl) 118:444-450

Richards JG, Mohler H (1984): Benzodiazepine receptors. Neuropharmacology 23:233-242

Roberts GW (1992): Neuropeptides: Cellular morphology, major pathways, and functional considerations. In Aggleton JP (ed), The Amygdala: Neurobiological Aspects of Emotion, Memory, and Mental Dysfunction. New York, Wiley-Liss, Inc., pp 115-142

Rocha L, Tatsukawa K, Chugani HT, Engel JJ, Engel J Jr (1993): Benzodiazepine receptor binding following 
chronic treatment with naloxone, morphine and Metenkephalin in normal rats. Brain Res 612:247-252

Sanders SK, Shekhar A (1995): Anxiolytic effects of chlordiazepoxide blocked by injection of GABAA and benzodiazepine receptor antagonists in the region of the anterior basolateral amygdala of rats. Biol Psychiatry 37:473-476

Scheel-Kruger J, Petersen EN (1982): Anticonflict effect of the benzodiazpines mediated by a GABAergic mechanism in the amygdala. Eur J Pharmacol 82:115-116

Spruce BA, Jackson S, Lowry PJ, Lane DP, Glover DM (1988): Monoclonal antibodies to a proenkephalin A fusion peptide synthesized in Escherichia coli recognize novel proenkephalin A precursor forms. J Biol Chem 263:19788-19795

Tsuda M, Suzuki T, Misawa M, Nagase H (1996): Involvement of the opioid system in the anxiolytic effect of diazepam in mice. Eur J Pharmacol 307:7-14
Valverde O, Fournie-Zaluski MC, Roques BP, Maldonado R (1996): Similar involvement of several brain areas in the antinociception of endogenous and exogenous opioids. Eur J Pharmacol 312:15-25

Veinante P, Stoeckel ME, Freund-Mercier MJ (1997): GABAand peptide-immunoreactivities co-localize in the rat central extended amygdala. NeuroReport 8:2985-2989

Wuster M, Duka T, Herz A (1980): Diazepam-induced release of opioid activity in the rat brain. Neurosci Lett 16:335-337

Young WS, Kuhar MJ (1980): Radiohistochemical localization of benzodiazepine receptors in rat brain. J Pharm Exp Ther 212:337-346

Zhang HT, Xu ZM, Luo ZP, Qin BY (1996): Anxiogenic effect of naltrexone in social interaction test in rats. Chung-KuoYao Li Hsueh Pao-Acta Pharmacologica Sinica. 17:314-317 